\title{
Role of International Fund for Agricultural Development/ Community Based Agricultural and Rural Development Programme (IFAD/CBARDP) in Improving the Livelihood of Rural Women: A Case Study of Aliero Local Government Area, Kebbi State, Nigeria
}

\author{
${ }^{1}$ A.I. Illo, ${ }^{* 2}$ A.K, Ango, ${ }^{1} \mathrm{H}$. Usman, and ${ }^{12}$. Aminu \\ 'Department of Agricultural Economics \& Extension, Kebbi State University of Science and Technology, Aliero, Nigeria. \\ ${ }^{2}$ Department of Agricultural Extension \& Rural Development, Usmanu Danfodiyo University, Sokoto, Nigeria.
}

[ ${ }^{*}$ Corresponding author: Email aakamba2@yahoo.com; ;

\begin{abstract}
This study examined the role of IFAD/CBARDP on improving rural women's livelihood in Kebbi State, Nigeria. Multistage sampling technique was adopted to select 80 IFAD participating women. Structured questionnaire was used in data collection. Descriptive statistics was used to present the data obtained. Majority of the women were married, and at active productive ages. Qur'anic education was the common educational status of the participants. The findings also reveal that all the IFAD participating women were provided with assistance based on needs and interest and the common assistance provided was the training on tailoring, knitting, soap and cream making and later the participants were provided with such machines. In addition, the participants were also provided cash loan. The programme has lead to improvement of the living standards of the participants after programme participation. Attitudinal dispositional test using 3 points Likert's scale reveal that the participating women strongly agreed that the programme has improved their living standard, the loan was adequate, and all the assistance provided was based on their needs and interest. It is concluded that the participating women were involved in decision making, most especially on the assistance provided, and the management of the assistance. It's recommended that effort should be geared towards increasing women participation in any intervention programme that could uplift the livelihood of the rural communities.
\end{abstract}

Keywords: Role, IFAD/CBARDP, Poverty Reduction, participating women, Kebbi State.

\section{INTRODUCTION}

International Fund for Agricultural Development (IFAD) is an international financial institution with the mandate to eradicate rural poverty in developing countries by helping rural populace to achieve higher incomes and food security. Dieter (2000) reported that IFAD developmental goal is to reduce poverty among the rural poor through sustainable improvement in household food security and incomes. In order to contribute to this goal IFAD provides improved financial and non-related financial services in rural areas, with special emphasis on women and the poor, not as beneficiaries of charity, but as commercial users or user-owners of sustainable financial institutions. Nigeria poverty reduction agency (2008) reported that IFAD has since 1985 financed different programmes and project that have direct bearing with poverty reduction in Nigeria.

The effort by IFAD towards poverty reduction and improving the livelihood of rural women led to the implementation of the Community Based Agriculture and Rural Development Programme (CBARDP). CBARDP was established after several studies indicated that poverty is becoming endemic in some northern states with fragile ecosystem in Nigeria (IFAD, 2006). The programme operates in eight northern Nigeria states namely: Borno, Jigawa, Kano, Katsina, Kebbi, Sokoto, Yobe, and Zamfara with the aim of reducing the level of poverty affecting the rural populace of the benefitting states (CTA, 2010).

In Kebbi State, Aliero Local Government Area is one of the International Funds for Agricultural Development IFAD/CBARDP participating Local Government Areas. The major objective of the programme is to improve the livelihoods and living conditions of the rural poor with special emphasis on the needs of women and vulnerable groups (IFAD, 2004). IFAD is an agency of the United Nations, dedicated to eradicate poverty and hunger in developing countries. It works in remote rural areas of the world to help countries achieve the millennium development goals. Through low - interest loans and grants, IFAD tackles poverty not just as lender but as an advocate for small farmers, herders, fisher folk, landless workers, artisans and indigenous 
people who live in rural areas and which represent $75 \%$ of the world's 1.2billion extremely poor people.

Women in Nigeria form an active and reserve labour force but they rarely own the means of productions (Rahman, 2004). However, the position of women in meeting challenges of agricultural development cannot be over emphasized. In a typical African setting, woman make a significant contribution to food production, they provide $60-80 \%$ of agricultural labour and are responsible for $80 \%$ of food crop processing (Mgbada, 2002; Rahman, 2004). Nevertheless, they have little or no access to productive assets. Despite the fact that women folk play an essential and dynamic role in economic life, they remain seriously disadvantaged in terms of access to health, education, financial and agricultural extension services due to their low economic status and are in most cases denied of access to loan facilities for lack of collateral securities (Modupe, 2008). According to Amaka (2009) women's poverty is attributable to by the absence of economic opportunities, autonomy, lack of access to economic resources, including credit, land ownership and inheritance, lack of access to education and support services and minimal participation in the decision making process.

The women in the study area, like their fellows in other parts of Nigeria and Africa at large, were also faced with similar problems and even sometimes more striking due to tradition and religious restrictions. In this area, married women are not in most cases allowed to go to farm and or engaged in other agricultural activities, and in decision making and any business transaction with men without the consent of their husbands. Yemisi and Aisha (2009) reported that it's striking that that despite the fact that women when compared with their male counterpart, takes the leading agricultural activities were either not or minimally involved in decision making regarding agricultural development, an inequality that constitutes a bottleneck to development.

In realization that women's empowerment and the improvement of their economic status are essential for development, it is imperative therefore to examine the role IFADICBARDP has played in terms of improving the livelihood of women in the study area through achieving the under listed objectives.
1. Description of the personal characteristic of the participants.

2. Finding out the various services/assistance provided to the participants by the programme

3. Determining the income of the participants before and after the programme

4. Assessing the attitude of the participants towards the programme

\section{METHODOLOGY \\ The study Area}

Aliero Local Government is one of the Local Government Areas under Gwandu Emirate of Kebbi state. It covers a geographical land area of 412 square kilometres with an estimated population of about 125,783 inhabitants (NPC, 2006). It is bordered to the north- east by Gwandu Local Government Area, to the south- west by Jega Local Government Area, to the east by Tambawal Local Government Area of Sokoto state, and to the north-west by Birnin- Kebbi Local Government Area. The study area is located on latitude $12^{\circ} 16^{\prime} 42^{\prime \prime}$ north and $12.2^{\circ}$ north and longitude $4^{\circ} 27^{\prime}$ $6^{\prime \prime}$ east and $4.45^{\circ}$ east of the equator. The climate of the area is generally characterized by high temperatures ranging between March and May, with annual temperatures varying between $38^{\circ} \mathrm{C}$ to $42^{\circ} \mathrm{C}$ and the area experiences harmattan wind between late November to early February, with temperatures as low as $23^{\circ} \mathrm{C}$.

The study area is located in the Sudan Savannah agroecological zone of Nigeria, and it experiences serious moisture deficiency for greater part of the year. Rainfall usually begins in early May, while heavy fall is experienced between July and October with mean annual rainfall varying between $500 \mathrm{~mm}$ to $800 \mathrm{~mm}$. The climate of the area encourages the production of crops and rearing of animals both during rainy and dry seasons of the year, which makes majority of the inhabitants to choose peasant farming as an occupation.

The topography of the area is flat and slightly undulating with compact, stony brown soil. Over two thirds of the population of the study area engages in agricultural production, mostly arable crops alongside cash crops with animal husbandry. The predominant ethnic group of the area is Hausa/ Fulani with many tribes of Nigeria and other neighbouring countries with and Islam is their major religion. 
Nigerian Journal of Basic and Applied Science (June, 2015), 23(1): 23-30

\section{Sampling procedure and 'sample size}

The sample population of the study consisted of all the IFAD/CBARDP participating women farmers in the study area. The IFAD/CBARDP Local Government desk officer was consulted to obtain the number of the women participants or beneficiaries in the project. To achieve the sample size of the study, multi-stage sampling technique was used. The first stage involved the selection of two districts from the three districts in the local government area. The second stage involved the selection of two villages from the selected districts and the third stage involved the random selection of 40 women participants from each of the selected villages (JigaBirni and UnguwarLawal). The sample size of the study to constitute 80 participating women.

\section{Data Collection}

Primary and secondary data were used for this study. The primary data was sourced through the administration of structured questionnaire to the participating women. The secondary data was obtained from relevant literature such as text books, journals, proceedings, internet, and official documents from IFAD/CBARDP offices.

\section{Data Analysis}

Descriptive statistics and 3 points Likert scale were used in analyzing the data obtained. The descriptive statistic in form of mean, frequency distribution and percentage were used while Likert scale ratings of $S A$ SD where Strongly Agree (SA) was appointed 3 points, Agree - A (2 points), Disagree - D (1 point).

\section{Measurement of variables}

The dependent variable of the study is role of IFAD in poverty reduction while the independent variables are personal characteristics of the participants, assistance provided, and attitude of the participants towards the programme. The age of the participants were measured in years; marital status was measured based on single, married, divorced and widowed; participants' educational background was measured according to Qur'anic education, primary education, secondary education, and tertiary education. The participants' occupation was measured based on crop production, livestock production, agro-processing, petty trading, craft and civil service. Assistance provided by the programme was measured based on tailoring, knitting machine, soap making, bread baking, cream making and mode of providing the assistance was measured based on demand and supply while the income of the participants was measured based on earnings before and after the programme.

Three points Likert scale of SA- D was used to measure the participants' attitude towards the programme. The attitudinal statements are: IFAD/CBARDP has improved the living standard and income level of the women; the programme had provide adequate loan to women in your community; the programme has addressed the needs and interest of women; the loan provided by the programme was adequate.

\section{RESULTS AND DISCUSSION}

\section{Participants' socio-economic characteristics Age of the participants}

Table 1 show the distribution of rural women participants according to their age. More than $46 \%$ of the participants were middle aged women between the ages of $41-50$ years. Those between the ages of $31-$ 40 constitute $33.8 \%$ of the participants, $10.0 \%$ were those participants at the ages between $21-30$ years and $10 \%$ of the participants were within the ages of 51 years and above. This finding is in line with Ayoade et al. (2009) who in a related study on women in livestock production reported that majority of the women were middle aged and the proportion of younger women in livestock production was relatively small when compared with that of the middle ages. The middle aged women constituted the majority of the participant in the project and these group of women are considered to be at their prime ages and more active and productive to learn and handle any assistance provided by the programme.

\section{Marital status of the Participant}

The result in Table 1 shows that majority (86.3\%) of the participating women were married, $6.3 \%$ were divorced, and $5.0 \%$ were widowed while only $2.5 \%$ of them were single. The result suggests that the married women benefited more from the programme as against single, divorced and widowed because the assistance provided can be managed indoors not necessarily transact business with males outdoor that goes contrary with the religion and tradition of the people in the study area. This findings corroborate with Yahaya and Ango (2000) who reported that majority of farmers in north west Nigeria in compliance with Islamic culture practice backyard farming and rearing of domestic animals and managing businesses indoor. 


\section{Educational attainment}

Majority $(80.0 \%)$ of the women participants attained Qur'anic education, while only $(20.0 \%)$ of them attained western education at different levels. This finding is in agreement with Ayoade et al. (2009) who posit that the educational status of women in livestock production is low. The majority of participants that benefited from the project attained Qur'anic education compared to western education and may help them to accept and adopt any new innovation provided to them by the programme. This findings is in line with Rogers (1995) reported that education is an important factor that helps in acceptance and adoption of innovations.

\section{Occupations of the participants}

As shown in Table 1, majority (61.25\%) of the women participants engaged in agro-processing, $12.5 \%$ were in to petty trading , $13.75 \%$ engaged in crafts as their main occupation , $10 \%$ reared livestock, while only $2.5 \%$ of the participants considered crop production as their main occupation. The findings imply that petty trading and agro-processing is the major occupation engaged by the participants because it is one of the businesses recognized by the society in the study area. This finding is in accordance with Ezeani (1995) who posits that about $75 \%$ of Nigerians living in the rural areas are farmers, artisans, craftsmen, and traders.

\section{Assistance provided to the participants \\ Cash Assistance}

As indicated in Table 2, $27.5 \%$ of the women participants enjoyed the assistance of N 21,000 and above and $25 \%$ of them were provided with the sum of less than $N 5,000$. The findings imply that all the participants were assisted with certain amounts of money that helps in engaging them in meaningful business that attracts certain amount of money that translates to improvement of livelihood.

Table 2 further reveals that majority (95\%) of the participating women were provided with the assistance based on demand while only (5\%) were just supplied with the assistance. The findings imply that the participating women were fully allowed to choose the skills or assistance required that help in reducing the level of poverty affecting them. This findings is in line with Dieter (2014) who reported that IFAD is confident that, through a system approach it can substantially contribute to expanding the frontier of institutional sustainability and outreach to the poor by playing a catalytic role and takes responsibility, in close cooperation with other stakeholders, for the continued expansion of the frontier.

\section{Assistance provided by the programme}

As further indicated in Table 2, majority (62.5\%) of the women participants were assisted by training and provision of tailoring machines, $13.8 \%$ were trained on cream making and $12.5 \%$ were trained and provided with knitting machines, while few $(11.3 \%)$ falls among those who were trained and assisted with machine for soap making. The findings indicate that majority of the women participants that benefited from the programme were trained and later provided with the necessary machine and which could be due to the fact that any business engaged by the women indoor is the business recognized by the society in the study area. This is because by the tradition and the injunctions of the Islamic religion, married women are not allowed to operate businesses outside of their matrimonial homes.

Income of the respondents, before and after participating in to the programme/month

As shown in Table 3, the frequency of the participants earnings of $\mathrm{N} 14,000$ and above before and after the programme has increased from $8.8 \%$ to $68.8 \%$ and the earnings of $\mathrm{N} 11,000-\mathrm{N} 14,000$ has also increased from $3.8 \%$ before participating in to the programme to $18.8 \%$ after participating in to the programme. The findings reveal that the number of participating women earnings has increased and as such it is evident that the programme succeeded in uplifting the living standard of the participating women by increasing their income. This finding is in accordance with Dieter (2014) who reported that one of the IFAD developmental goals is to reduce poverty among the rural poor through sustainable improvement in household food security and incomes. In order to contribute to this goal IFAD provide improved financial and non-related financial services in rural areas.

\section{Attitudinal test of the women participants}

The attitudes of the participants towards IFAD programme was measured using 3 and 4 points Likert scale. Both positive and negative statements were used to solicit information from the participating women on the operations of the IFAD programme. Three points Likert scale was used for positive statements while for negative statements, 4 points Likert scale was used. The attitudinal statements are written in bold. 
Nigerian Journal of Basic and Applied Science (June, 2015), 23(1): 23-30

Table 1: Personal Characteristics of the Participants in Aliero Local Government Area, Nigeria $(n=80)$

\begin{tabular}{lcc}
\hline Variable & Frequency & Percentage \\
\hline Age of the respondents & 8 & \\
$21-30$ years & 27 & 10.00 \\
$31-40$ years & 37 & 33.80 \\
$41-50$ years & 8 & 46.20 \\
51 years and above & 2 & 10.00 \\
Marital status & 69 & \\
Single & 5 & 2.50 \\
Married & 4 & 86.30 \\
Divorced & 12 & 6.30 \\
Widowed & 2 & 5.00 \\
Educational attainment & 64 & \\
Primary school & 2 & 15.00 \\
Secondary school & & 2.50 \\
Qur'anic school & 49 & 80.00 \\
Tertiary institutions & 10 & 2.50 \\
Occupation & 11 & \\
Agro-processing & 8 & 61.25 \\
Petty trading & 2 & 12.50 \\
Craft & & 13.75 \\
Livestock rearing & & 10.00 \\
Crop production & & 2.50 \\
\hline Source: fild survey & 2013 &
\end{tabular}

Source: field survey, 2013

Table 2: Mode and Assistance Provided to the Participants by the Programme $(n=80)$

\begin{tabular}{lcc}
\hline Variables & Frequency & Percentage \\
\hline Provision of the Assistance & 76 & 95.00 \\
Based on demand & 4 & 5.00 \\
Jus supplied & & \\
Cash Assistance & 20 & 25.00 \\
Less than N5,000 & 16 & 20.00 \\
N 5,000-N10,000 & 6 & 7.50 \\
N 11,000-N15,000 & 16 & 20.00 \\
N 16,000-N20,000 & 22 & 27.50 \\
N 21,000 and above & & \\
Trainings and machineries provided. & 50 & 62.50 \\
Tailoring & 10 & 12.50 \\
Knitting machines & 9 & 11.30 \\
Soap making & 11 & 13.80 \\
Cream making & &
\end{tabular}

Source: Field survey, 2013

The programmed has improved the living standard and income level of women

This attitudinal statement used to solicit the interest of the women participants were on level of wealth, comfort, and necessities available to a certain socioeconomic class in a certain geographical area. As indicated in Figure 1, majority (83.8\%) of the participating women strongly agreed that the programme has improved their livelihood, $13.8 \%$ of the women agreed that the programme has improved their living standard through increased of income level, while only $(2.5 \%)$ of the participants disagreed that the project has improved their living standard. The attitudinal test findings therefore reveal that 
participating in to IFAD Programme has positive impact towards reducing poverty of the women participants through improving their income and living standards.

\section{The programme had provided loans to the women participants}

Figure 2 shows that majority (61.3\%) of the participating women strongly agreed that the programme provided them with adequate loan, $36.3 \%$ agreed that the programme had provided them with adequate loan while only $(2.5 \%)$ disagreed that the loan provided by the programme was adequate. The findings imply that most of the participating women in the study area were strongly of the view that the loan provided to them by the programme was adequate and which helped them in generating income that aided in reducing poverty affecting them.

Table 3: Distribution of participants' income/month before and after participating in the programme $(n=80)$.

\begin{tabular}{|c|c|c|c|c|c|}
\hline $\begin{array}{l}\text { Variable } \\
\text { Income/before } \\
\text { programme }\end{array}$ & Frequency & Percentage & $\begin{array}{c}\text { Variable } \\
\text { Income/after } \\
\text { programme }\end{array}$ & Frequency & Percentage \\
\hline$<\mathrm{N} 1,000$ & 27 & 33.8 & $<\mathrm{N} 1,000$ & 2 & 2.50 \\
\hline N 2000 - N 5000 & 36 & 45.0 & N $2000-N 5000$ & 3 & 3.80 \\
\hline$N 6,000-N 10,000$ & 7 & 8.8 & $N 6,000-N 10,000$ & 5 & 6.30 \\
\hline $\mathrm{N} 11,000-\mathrm{N} 14,000$ & 3 & 3.8 & $N 11,000-N 14,000$ & 15 & 18.80 \\
\hline $\mathrm{N} 14,000$ and above & 7 & 8.8 & N 14,000 and above & 55 & 68.80 \\
\hline
\end{tabular}

Source: field survey, 2013

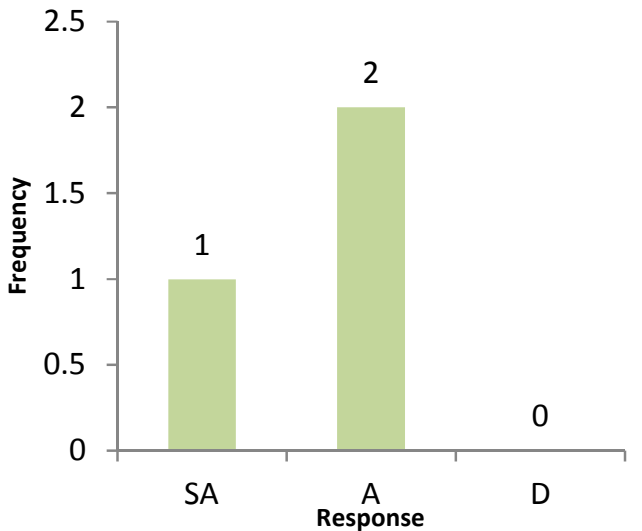

Figure 1: Impact of the programme on income and livelihood of the beneficiaries

The programme has addressed the needs and interest of participating women

As further indicated in Figure 3, most $(57.5 \%)$ of participating women were strongly of the view that the programme has involved them by soliciting their needs and interest, $36.3 \%$ of the women have agreed that the programme has addressed their needs and interest while only (6.3\%) participating women had disagreed that the programme provided them with the assistance based on their needs and interest. This implies that IFAD programme has followed and obeyed the recent

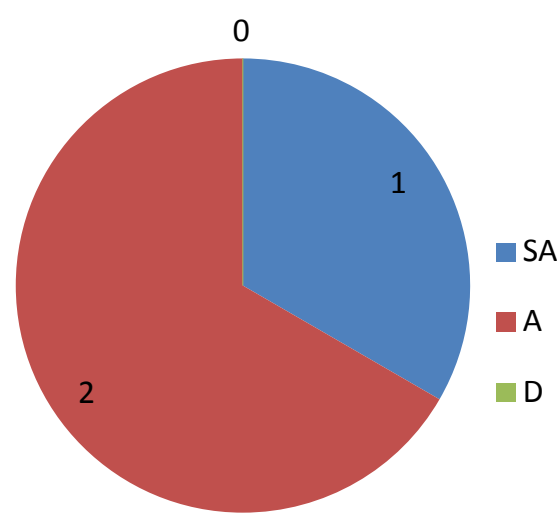

Figure 2: Adequacy of the loan provided to the beneficiaries by the programme

trend of involving community's in any project/programme that aimed at improving their livelihood by soliciting their needs and interest based on which assistance is provided to them. In the contrast, IFAD as a programme has gone contrary to the tradition of the study area where women are not involved in decision making particularly in anything to do with inheritance of land and its development, acquiring and or having access to loan and involvement in any decision on programme aimed at developing and or providing assistance to the community members. These 
findings are in line with Yemisi and Aisha (2009) who reported that it's striking that despite the fact that women when compared with their male counterpart take the leading agricultural activities were either not or minimally involved in decision making regarding agricultural development, an inequality that constitutes a bottleneck to development.

\section{CONCLUSION}

That majority of the participating women were married, had Qur'anic education and were in active and productive ages. The participating women were provided assistance based on needs and interest and the common assistance provided was training on tailoring, knitting, soap and cream making, cash and were later provided with the operating machines leading to increase in income and improvement of the participant's standard of living. It is concluded that the participating women were involved in decision making, most especially on the assistance and the management of the assistance provided.

\section{Recommendations}

Based on the findings of the study, the following recommendations are offered.

1. The IFAD/CBARDP programme is recommended to cover more local government areas, districts and villages in the study area.

2. More women should be encouraged to participate in IFAD/CBARDP intervention programme purposely to uplift their livelihood as they constitute larger proportion of vulnerable and poorest segment of rural society.

3. The programme should provide adequate cash loans and other incentives to the participating women.

4. Participating women are advised to judiciously utilize the assistance provided and pay back the loan in time so that others can also enjoy the same.

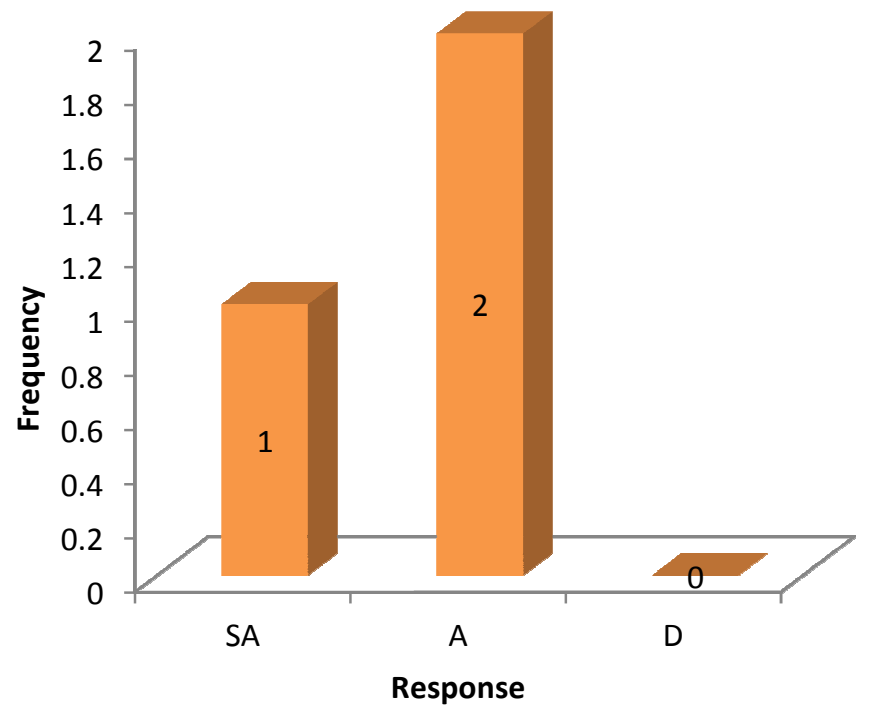

Figure 3: Addressing the needs and interest of the participants. 


\section{REFERENCES}

Amaka, C. (2009) Amaka for kids, Nigeria: Women and poverty reduction in Nigeria. Retrieved from rhetoric to action, http/www.tigweb.org/express/panorama/article. $\mathrm{htm}$ on the 25th March, 2013 at 03:45Pm.

Ayoade, J.A., Ibrahim, H.I., and Ibrahim, H.Y. (2009).Analysis of women involvement in livestock production in Lafia Area of Nasarawa State, Nigeria.Livestock Research for Rural Development, 21 (220). Retrieved May 21st, 2014, from http://www.Irrd.org/lrrd21/12/ayoa21220.htm at 9:01Am.

Dieter, S. H. (2000). IFAD rural finance policy.A working paper / university of Cologne, Development Research Centre, No. 2000, 6.Retrieved from www.econstor.eu on the $7^{\text {th }}$ May, 2014 at $1.02 \mathrm{Pm}$.

Ezeani, E.A. (1995). National planning and rural development in Nigeria: in Eboh, E. C., Okoye, C. $U$. and Ayichi, D (Eds) Rural development in Nigeria: Concepts, processes and prospects. Enugu: Auto century publishing company: pp5472

CTA (2010). A current awareness and bettering for ACP agriculture, CTA issue 53

International Fund for Agricultural Development (IFAD) (2004). Socio - economic and gender analysis. A training workshop for IPAD projecting Nigeria, Katsinanigeria.22-26 November, 2004

International Fund for Agricultural Development (IFAD) (2006). The effects of poverty on artisanal fishery, south - west Madagascar. Retrieved from www.reefdoctor.org/.../effectpoverty - artisanal fisheries - SW - Madagascar - project - proposal - No - 07, PDF on the $13^{\text {th }}$ August, 2010 at 3:04Pm
Mgbada, .J.U. (2002). Production of staple crops by rural women in Enugu and Ebonyi states: lessons for enhancing poverty alleviation programmes. In: Olowu T.A (eds) agricultural extension and poverty alleviation in Nigeria. Proceeding of the agricultural extension society of Nigeria: pp10-12

Modupe, F. M. (2008). Economic implication of poverty programmes on rural women in Ondo state. Case study of country women association of Nigeria. A paper presented at workshop on gender and sustainable development, gender dimension, Ibadan, Nigeria.

National Population Commission (NPC) (2006). Nigeria head to head count, 2006

Poverty reduction around the World (2008). In causes of poverty (2009) (assessed on Retrieved from http/www.globalissues.org/issue/g/causesofpovert $y$ on $12^{\text {th }} \quad$ April 2014 at $12: 42 \mathrm{Pm}$

Rahman, S.A. (2004).Gender differential in labour contribution and productivity in farm production, an empirical evidence from Kaduna State of Nigeria. A Paper presented at the national conference on family, held at new theatre complex, Benue State University, Makurdi, Nigeria on the $1^{\text {st }}-5^{\text {th }}$ march, 2004

Rogers, E.M. (1995). Diffusion of Innovation, fourth edition.The Free Press, New York: pp1-440

Yahaya M.K. and Ango, A.K. (2000). Socio-economic and environmental effects of Bakolori irrigation and Fadama development projects in Sokoto/Kebbi watershed. Moor Journal of Agricultural Research, 4(1): 12-24.

Yemisi, I.O. and Aisha, A.M. (2009). Gender issues in agriculture and rural development in Nigeria: The role of women. Humanity and Social Sciences Journal, 4(1): 19-30. 